Article

\title{
Waves of Change: Towards Ecosystem-Based Management to Climate Change Adaptation
}

\author{
Luciana Yokoyama Xavier ${ }^{1, *(\mathbb{C})}$, Maila Guilhon ${ }^{1}$, Leandra Regina Gonçalves ${ }^{1,2}\left(\mathbb{D}\right.$, Marina Ribeiro Corrêa ${ }^{3}$ \\ and Alexander Turra ${ }^{1}$
}

check for updates

Citation: Xavier, L.Y.; Guilhon, M.; Gonçalves, L.R.; Corrêa, M.R.; Turra, A. Waves of Change: Towards Ecosystem-Based Management to Climate Change Adaptation. Sustainability 2022, 14, 1317. https:// doi.org/10.3390/su14031317

Academic Editors: Chiranjeewee Khadka and Pavel Cudlin

Received: 14 December 2021

Accepted: 11 January 2022

Published: 25 January 2022

Publisher's Note: MDPI stays neutral with regard to jurisdictional claims in published maps and institutional affiliations.

Copyright: (C) 2022 by the authors. Licensee MDPI, Basel, Switzerland This article is an open access article distributed under the terms and conditions of the Creative Commons Attribution (CC BY) license (https:// creativecommons.org/licenses/by/ $4.0 /)$.
1 Instituto Oceanográfico, Universidade de São Paulo, São Paulo 05508-120, Brazil; maguilhon@usp.br (M.G.); goncalves.leandra@unifesp.br (L.R.G.); turra@usp.br (A.T.)

2 Instituto do Mar, Universidade Federal de São Paulo, Santos 11070-100, Brazil

3 Instituto de Energia e Ambiente, Universidade de São Paulo, São Paulo 05508-900, Brazil; marina.ribeiro.correa@alumni.usp.br

* Correspondence: lyxavier@usp.br; Tel.: +55-11-30916594

\begin{abstract}
Coastal climate change impacts challenge policy and decision makers to adopt more effective adaptation measures. The ecosystem-based management approach can shift adaptation towards a more holistic, integrated and sustainable path. However, as countries work on strategies to adapt to climate change, the questions of if and how such agendas consider and operationalise ecosystembased management remains. As one of the world's largest coastal countries, Brazil can have a prominent role in advancing the implementation of ecosystem-based management to coastal zones. By analysing two national Brazilian climate change adaptation institutions, this article evaluates and discusses the country's advances in promoting climate change adaptations based on ecosystem-based management principles. Our findings show that, although Brazil has incorporated many ecosystembased management principles to climate change adaptation at the national level, greater attention should be given to operationalizing principles related to acknowledging uncertainties, sustainability, democracy and knowledge production and application. The challenges to implement these principles mirror historical challenges of Brazilian coastal management policies, such as balancing development and conservation, promoting social participation and implementing effective social-ecological assessments and monitoring programs. Policy makers, scientists and communities should be aware of the need to strengthen ecosystem-based management principles in the current adaptation agenda in order to enhance its capacity to foster adaptation and just coastal sustainability.
\end{abstract}

Keywords: climate change adaptation; ecosystem-based management; coastal management

\section{Introduction}

From the iced Antarctic lands, through the tropical forests, and reaching the austral tundra, no environment on Earth is free from climate change (CC) impacts. However, the devastation is more evident in coastal zones, where diverse and fragile ecosystems and unique ecosystem services and resources are threatened by human activities and CC [1,2]. CC affects sea level, wind and wave regimes, increases the number of extreme rainfall and temperature events, changes ocean water properties and lowers river basins contributions for sedimentary balance [3]. As a result, it may increase erosion and social-environmental vulnerability, incur property, lives, habitats and biodiversity losses, impair water availability by groundwater salinisation and threaten traditional cultures $[2,4]$. Therefore, management measures are pressing [4] and coastal development and governance must adapt to CC to prevent drastic environmental and livelihood consequences $[3,5]$.

In simple terms, adaptation means the "process of adjustment to actual or expected climate and its effect" [6] (p. 1578). Effective CC adaptation relies on the ability to promptly respond to changing social-ecological contexts, maintaining the ecosystem capacity to 
deal with changes [7]. It demands sound ecosystem knowledge from multiple knowledge systems [6], strategic long-term preventive actions [8] and constant monitoring to identify necessary management improvements [9]. Additionally, management focused on adaptation requires cross-level coordination to implement national policies at the local level, mainstream local adaptation to national and global initiatives [10-12], and overcome barriers related to institutional and social dimensions [13].

Ecosystem-based management (EBM) represents a promising approach to foster adaptation to CC [4,14]. Long et al. (2015) defined EBM as an interdisciplinary approach that balances ecological, social and governance principles at appropriate temporal and spatial scales. EBM recognises coupled co-evolving social-ecological systems and aims to involve stakeholders and knowledge systems in an integrated and adaptive process where systems boundaries and management proposals reflect societal choice [15] (p. 59). Scientific literature has discussed and reported EBM application worldwide [15-22], including its relation to CC [11,23]. However, EBM implementation is still incipient for coastal and marine areas and requires a better understanding of its application in policy-making [24].

If EBM is to guide CC adaptation, the related policies, plans, programs and projects must be compatible with its logic and principles. Thus, including EBM at the foundation of public policies would be the first step to promoting and guiding action [24,25]. Although under different nomenclatures, many international agencies advocate and have included EBM in norms and proposals [26,27]. Even though many environmental policies and plans consider EBM principles, subtle and blurred references to such principles can undermine its implementation [27] since the lack of understanding of what EBM entails and how it translates into actions are still barriers to be overcome [24,25,27].

Implementing CC adaptation in consonance with a holistic and integrative approach such as EBM can be an extra challenge for Brazil. This Global South country holds a high social-environmental vulnerability due to its extensive coastal zone, regional inequalities, vulnerable cities, limited information, deficient governance systems and limited adaptability [28-30]. As sea level rises over the large and prominent Brazilian coast, worsening its high social-environmental vulnerability, innovative CC adaptation is an urgent and overlooked necessity. However, as for many other recent CC adaptation instruments, it is still unclear if EBM principles guide policy-making and are sufficiently clear to support its implementation [27]. To address this gap and contribute to the discussion on how to move EBM from discourse to practical management actions, this article aims to evaluate if and how two planning instruments for CC adaptation in Brazil consider EBM principles. Based on an exploratory analysis, we discuss how EBM principles are considered or neglected in Brazilian CC adaptation strategy and how this can affect EBM implementation.

Although Brazil has incorporated many EBM principles to CC adaptation instruments at the federal level, there is still a need to include and operationalize Sustainability, Democracy and Knowledge principles. Our findings clarify where efforts should be targeted to promote ecosystem-based CC adaptation in Brazil and bring new insights to the worldwide discussion on operationalizing EBM principles.

\section{Climate Change Policies in Brazil}

The Brazilian coast has approximately $8500 \mathrm{~km}$ and encompasses many ecosystems such as sandy beaches, mangroves, rocky shores, estuaries, reefs and dunes [31]. It holds a prominent role in the national economy, concentrating ports, industries and a significant contingent of the population [30,32], all of which are under the threat of rising sea levels [28,32]. The Brazilian coast has large areas affected by an urbanisation process characterised by unequal access to public services and unbalanced income distribution, leading to precarious and informal settlements [33,34]. The poor land use planning and flawed management increase the vulnerability of this region, which is already facing CC impacts related to an increase in raining periods, flooding, coastal erosion and landslides $[28,35]$. 
Despite the urgency, adaptation to $\mathrm{CC}$ is an unconsolidated agenda in Brazil [3]. In the country, CC adaptation is under the National Policy on Climate Change (Law 12.187/2009), and its main instrument is the National Plan for Adaptation to Climate Change (PNA, in Portuguese) [36,37]. The PNA was developed by federal ministries in collaboration with state governments and the private sector, with the main goal of reducing CC's risks and vulnerabilities through strategic shifts in the social, natural, economic and infrastructure systems. It follows the United Nation Environment Program (UNEP) "ecosystem-based adaptation" proposal, broadly defined as an adaptation process that considers the role of ecosystem services in reducing the climate change vulnerability in multi-level societal and sectoral scales $[23,38]$. Although the ecosystem-based adaptation definition diverges from EBM, it includes many EBM principles [38], thus setting a means to implement EBM.

In the two volumes that comprise the plan, the PNA provides the directives and principles to CC adaptation and guides actions at sub-national levels through a strategic approach to planning considering 11 different themes: agriculture, biodiversity and ecosystems, cities, natural disasters, industry and mining, infrastructure (energy, transport and urban mobility), peoples and vulnerable populations, water resources, food and nutritional security and coastal zones. Each sectoral strategic approach is guided by individual goals. The coastal zone is the only spatially defined sector, given its strategic importance and vulnerability to CC impacts. The general goal of coastal zone adaptation is to develop climatic resilience based on a reliable diagnostic of CC impacts and vulnerabilities of specific coastal sectors.

The PNA guidelines for the $\mathrm{CZ}$ are materialized through other programs and projects to be implemented by different organizations and on different levels, as the National Program for Coastline Conservation (Procosta, in Portuguese) [39]. The Procosta is a permanent program for territorial planning and management. Its main goal is to generate nationwide data about coastal ecosystems and CC impacts to foster CC mitigation and adaptation alternatives at the local level. The actions of the program are organized in four strategic subprojects to define a common reference level for the coastline, develop a computer model for future CC scenarios, assess and develop strategies to face potential social-environmental and economic coastal risks and establish a long-term monitoring and management system for the coastline.

The PNA and Procosta are the foundation stones for the coastal zone's national adaptation strategy and guide programs and projects at other administrative levels. Both instruments present a general guidance (principles, directives and goals) and a propositive section (actions, outcomes and indicators). To foster EBM, these instruments are expected to provide enough clarity on how to apply its principles. Based on this assumption, our exploratory analysis focused on the two documents to discuss which (and how) EBM principles are considered in Brazil's CC adaptation strategy.

\section{Methods}

Our analysis considered 15 key EBM principles identified by Long et al. [15]. Principles were defined and discussed among authors to provide consistency to the analysis and grouped into six categories: Sustainability, Ecological, Management, Democracy, Knowledge and Scale (for more information, see Supplementary Materials). For CC adaptation strategy, we considered specific General Guidance and Propositive sections in both PNA and Procosta, with a focus on coastal areas (Table 1).

The documents were read first to identify sections and determine which principles should be incorporated into which section, considering sections' objectives. The "Decisions Reflect Societal Choice" principle was not considered as applicable to Procosta, given the instrument's focus on technical and scientific data. All the other principles were considered as applicable, including "Decisions Reflect Societal Choice" for PNA.

Following Guilhon et al. [27] and Gelcich et al. [25], the content analysis involved examining the text to identify the presence (explicit or implicit) of EBM principles. Extracts relating to the principles were ranked according to predefined scores: 0 if the principle 
should appear in the document/section but was not identified, 1 if the principle was indirectly/implicitly mentioned, 2 if the principle was directly/explicitly mentioned and easily identified (see Supplementary Materials for examples of extracts classified as 1 or 2).

Table 1. Documents, sections and descriptions of sections considered for analysing Brazil's climate change adaptation instruments: National Plan for Adaptation to Climate Change (PNA) and the National Program for Coastline Conservation (Procosta).

\begin{tabular}{cccc}
\hline Instrument & Document & Sections & Description of Section \\
\hline PNA & Vol. 1. General Strategy & $\begin{array}{c}\text { 3. Goals, vision and principles } \\
\text { 4. Specific goals and general } \\
\text { recommendations } \\
\text { Vol. } 2\end{array}$ & $\begin{array}{c}\text { General guidance-principles, directives } \\
\text { and goals }\end{array}$ \\
Procosta & Single volume & 3. Coastal Zone Strategy & $\begin{array}{c}\text { Propositive section-proposals for actions, } \\
\text { expected outcomes, goals and indicators } \\
\text { for monitoring }\end{array}$ \\
\hline
\end{tabular}

The document sections underwent a two-step analysis consisting of individual content analysis, clarification and ranking of extracts and collective discussion to reach consensus. This was done twice for each document. First, the number of extracts ranked as 1 or 2 for each section and instrument was computed for each principle. The scores were reduced to one value for principle (considering the higher value). Second, divergent classifications for a single principle (i.e., a single principle received two different scores for the same section/document) were registered. Final classifications were represented as radar charts (Figure 1).

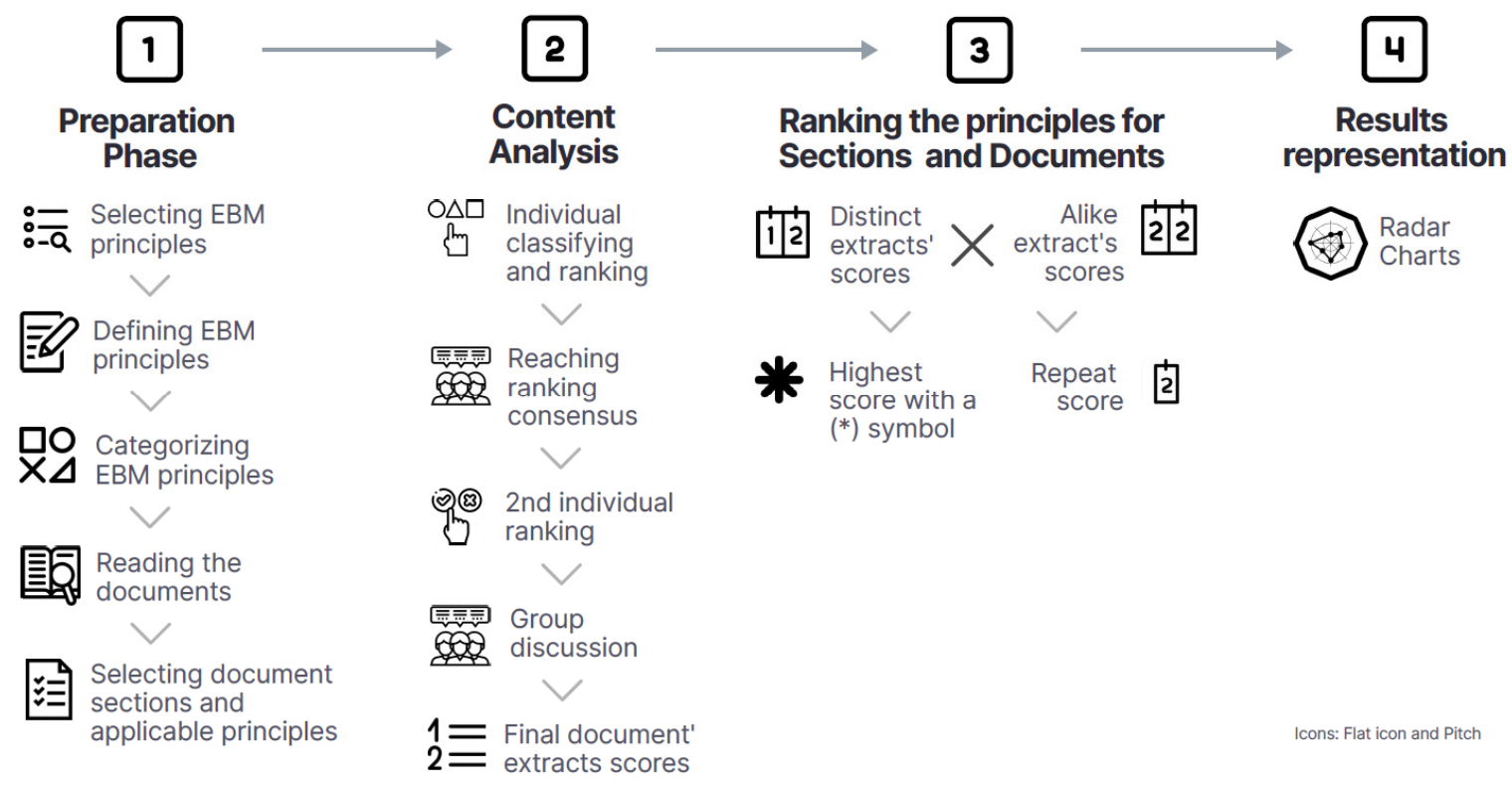

Figure 1. The systematic strategy adopted in the analysis performed in this study.

\section{Results}

The PNA explicitly mentioned all EBM principles, except "Acknowledge Uncertainty". However, a separate analysis of the General Guidance and Propositive sections showed that the inclusion of principles was not consistent throughout the document. For example, the General Guidance section failed to include the "Account for Dynamic Nature of Ecosystems" principle, and the Propositive section lacked the "Distinct Boundaries", "Sus- 
tainability" and "Decision Reflecting Societal Choice" principles (Table 2). Both sections of the documents mention most principles explicitly, except for "Appropriate Monitoring" and "Appropriate Spatial and Temporal Scale", which were identified only as implicit in the General Guidance section.

Table 2. Occurrence of Ecosystem-Based Management (EBM) principles in the Brazilian National Plan for Adaptation to Climate Change (PNA) and the National Program for Coastline Protection (Procosta). Mentions to the principles were classified as absent (0), implicit (1), explicit (2) or not applied (NA). The analysis considered the whole document (Final score), General Guidance and Propositive sections. For each principle, scores were classified to the higher value, and principles with different score classes (i.e., extracts classified as 1 and 2 for the same document/section) are marked as *

\begin{tabular}{|c|c|c|c|c|c|c|c|}
\hline \multirow{2}{*}{$\begin{array}{c}\text { EBM } \\
\text { Category }\end{array}$} & \multirow[b]{2}{*}{ Principles } & \multicolumn{3}{|c|}{ PNA } & \multicolumn{3}{|c|}{ Procosta } \\
\hline & & Final Score & $\begin{array}{l}\text { General } \\
\text { Guidance }\end{array}$ & $\begin{array}{l}\text { Propositive } \\
\text { Section }\end{array}$ & Final Score & $\begin{array}{l}\text { General } \\
\text { Guidance }\end{array}$ & $\begin{array}{l}\text { Propositive } \\
\text { Section }\end{array}$ \\
\hline Core & Sustainability & $2 *$ & 2 & 0 & $1^{*}$ & 1 & 0 \\
\hline \multirow[t]{3}{*}{ Ecological } & $\begin{array}{l}\text { Account for Dynamic } \\
\text { Nature of Ecosystems }\end{array}$ & $2 *$ & 0 & 2 & $2 *$ & 2 & $2 *$ \\
\hline & $\begin{array}{l}\text { Consider Ecosystem } \\
\text { Connections }\end{array}$ & 2 & 2 & 2 & $2 *$ & 0 & $2 *$ \\
\hline & $\begin{array}{l}\text { Ecological Integrity and } \\
\text { Biodiversity }\end{array}$ & 2 & 2 & 2 & $2 *$ & 0 & 2 \\
\hline \multirow[t]{3}{*}{ Management } & Adaptive Management & $2 *$ & $2 *$ & 2 & $1 *$ & 0 & 1 \\
\hline & Integrated Management & 2 & 2 & 2 & $2 *$ & 0 & 2 \\
\hline & Appropriate Monitoring & $2 *$ & 1 & 2 & $2 *$ & 0 & 2 \\
\hline \multirow[t]{3}{*}{ Democracy } & $\begin{array}{l}\text { Recognise Coupled } \\
\text { Social-Ecological } \\
\text { Systems }\end{array}$ & $2 *$ & $2 *$ & $2 *$ & $2 *$ & 0 & $2 *$ \\
\hline & $\begin{array}{l}\text { Decision Reflect } \\
\text { Societal Choice }\end{array}$ & $2 *$ & $2 *$ & 0 & $\mathrm{~N} / \mathrm{A}$ & $\mathrm{N} / \mathrm{A}$ & $\mathrm{N} / \mathrm{A}$ \\
\hline & $\begin{array}{l}\text { Stakeholder } \\
\text { Involvement }\end{array}$ & $2 *$ & $2 *$ & $2 *$ & $2 *$ & 0 & $2 *$ \\
\hline \multirow[t]{3}{*}{ Knowledge } & $\begin{array}{l}\text { Acknowledge } \\
\text { Uncertainty }\end{array}$ & 0 & 0 & 0 & 0 & 0 & 0 \\
\hline & $\begin{array}{l}\text { Use of Scientific } \\
\text { Knowledge }\end{array}$ & $2 *$ & $2 *$ & $2 *$ & $2 *$ & $2 *$ & $2 *$ \\
\hline & Interdisciplinarity & $2 *$ & $2 *$ & 2 & $2 *$ & 1 & $2 *$ \\
\hline \multirow[t]{2}{*}{ Scale } & Distinct Boundaries & $2 *$ & $2 *$ & 0 & $2 *$ & 0 & 2 \\
\hline & $\begin{array}{l}\text { Appropriate Spatial and } \\
\text { Temporal Scale }\end{array}$ & $2 *$ & 1 & $2 *$ & $2 *$ & 2 & $2 *$ \\
\hline
\end{tabular}

As an instrument to operationalise the PNA in different levels, Procosta includes the same EBM principles considered as applicable to PNA, except "Decision Reflect Societal Choices". Following PNA, Procosta lacks the "Acknowledge Uncertainty" principle, while most principles were explicitly mentioned (Table 2). Both "Sustainability" and "Adaptive Management" principles, ranked as implicitly mentioned for the document, were only present in one section. "Sustainability" was identified in the General Guidance section but was absent from the Propositive one, and "Adaptive Management" was identified only in the Propositive section.

The analysis of the percentage scores (\% of explicit and implicit mentions) evidences the potential for practical EBM implementation by the two CC adaptation instruments (Figure 2). Considering the instruments as a whole (Figure 2a,b), the frequency of explicit mentions to EBM principles was higher than the implicit ones, especially for Ecological and Management categories in both Documents and Scale categories in Procosta. For the 
Propositive sections, note that no explicit mentions to the "Sustainability" principle were identified. PNA Propositive sections followed the trend observed for the entire document. It considers the Ecological and Management categories but references to the principles of "Sustainability", "Decisions Reflects Societal Choice", "Acknowledging Uncertainty" and the "Recognition of Distinct Boundaries" were not identified (Figure 2b). Thus, the Procosta Propositive section diverged little from the entire document.

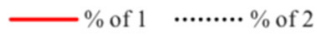

a) PNA - entire document

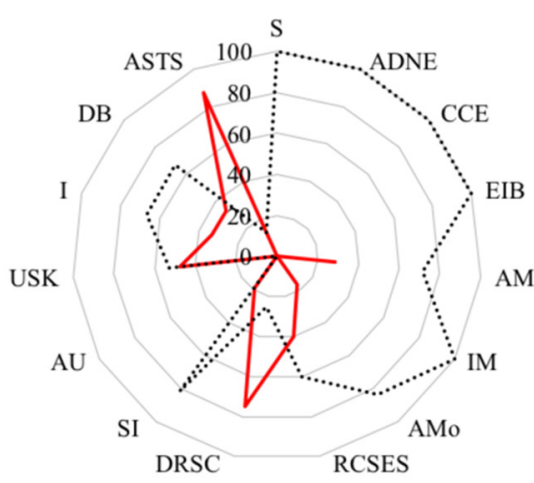

c) PNA - Propositive section

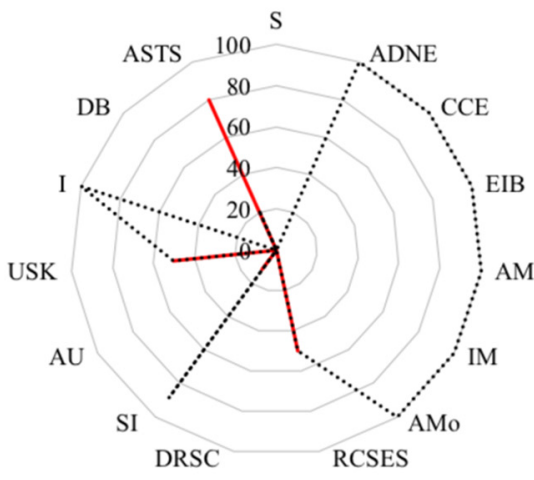

b) Procosta - entire document

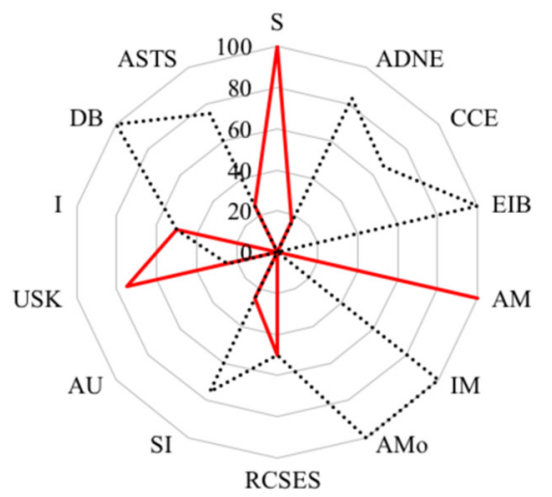

d) Procosta - Propositive section

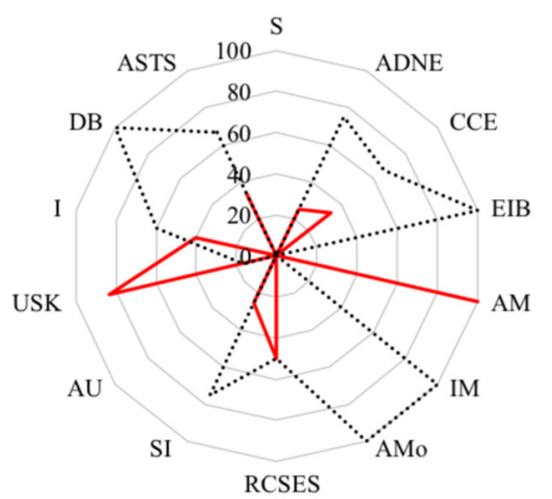

Figure 2. Percentage scores (percentages of extracts classified as 1 (solid line) and 2 (dotted line)) in the analysis of (a) the National Plan for Adaptation to Climate Change (PNA) and (b) Brazilian National Program for Coastline Protection (Procosta) as a whole and in the analysis of the (c) Propositive section of the PNA and (d) Procosta. The categories and principles considered were: S-Sustainability; Ecological (ADNE-Account for Dynamic Nature of Ecosystems; CEC - Consider Ecosystem Connections; EIB-Ecological Integrity and Biodiversity); Management (AM-Adaptive Management; IM-Integrated Management; AMo-Appropriate Monitoring); Democracy (RCSES-Recognise Coupled Social-Ecological Systems; DRSC—Decision Reflect Societal Choice; SI-Stakeholder Involvement); Knowledge (AU—Acknowledge Uncertainty; USK-Use of Scientific Knowledge; I-Interdisciplinarity); and Scale (DB-Distinct Boundaries; ASTS-Appropriate Spatial and Temporal Scale).

\section{Discussion}

Our analysis of the PNA and Procosta shows that EBM principles are a structuring part of the Brazilian CC adaptation agenda. The documents translate most principles into goals and actions enabling EBM for CC adaptation in coastal areas. However, more than evidence of the principles' presence, our analysis calls attention to those absent or poorly represented instruments. Improving the potential to operationalise EBM for CC adaptation requires increasing the applicability of all principles and categories. Focusing on each instrument's propositive sections, it is noticeable that while Ecological and Management 
categories are usually explicitly mentioned, greater attention must be given to Democracy, Knowledge and Scale categories when moving from theory to practice.

With the consolidation of the EBM agenda, global agencies and commitments recognise its potential to promote sustainability and advocate for its implementation $[26,40]$. According to the Convention of Biological Diversity Secretariat, "There is no single way to implement the ecosystem approach (... ). Indeed, there are many ways in which ecosystem approaches may be used as the framework for delivering objectives of the Convention in practice" [41] (p. 6). Thus, EBM should be adapted and applied to several social-ecological contexts and scales and translated from international agendas into policies at the national and sub-national levels; thus, governmental commitment is crucial.

For its explicit reference to UNEP's "ecosystem-based adaptation" approach and potential to link sectoral policies and stakeholders under a common goal, the PNA is a pioneering legal instrument to promote EBM. National surveys have reported a few initiatives to implement EBM in Brazil; among them, the ones related to CC adaptation are expected to trigger a new cycle of EBM implementation [23,42]. However, if not translated into practical and focused actions proposals, goals are insufficient to promote management and sustainability changes.

Translating EBM principles into operational management measures is an effort faced by managers, scientists and other interested practitioners [24,25]. In theory, explicit reference to EBM principles in sound directives and guidelines to be implemented at different administrative levels can lower the chances of misinterpreting or disregarding a principle when translating it into actions [27]. Thus, although policy implementation is a more complex process, and analysing it involves considering all policy cycle phases and political wills [43], understanding if and how key instruments address EBM shed light on possible pathways to advance with the process.

The analysis of both instruments' percentage scores (Figure 2) reveals an imbalance between categories with more explicit mentions than others, with remarkable similarity considering General Guidance and Propositive sections. As an instrument that operationalises the PNA, we expected that Procosta would provide more explicit mentions of EBM principles, especially for its Propositive section. However, results show that while Procosta has advanced in providing more detailed guidance for the Scale category, explicit mentions to other categories were less frequent than in PNA.

The first thing that calls for immediate action is that references to the "Sustainability" principle are absent in the Propositive sections of both documents. However, this is a foundational principle for PNA. The term sustainability indicates the desired state in which there should be a balance from the environmental, social and economic goals maintained over the generations. Given the sustainability principles' central position in current development discussions (as in Agenda 2030 [40]) and the very general and broad nature of the definition applied in this analysis, it was expected that this principle would be explicitly mentioned in all sections of the documents.

Our results, however, show that the proposals for actions failed to address the multiple aspects of sustainability, including equity and justice, which highlight the social dimension within the just sustainability approach [44]. Although references to environmental sustainability are recurring, and the documents tackle sustainability's social dimension, no proposal for action addressed the three dimensions at once. In PNA and Procosta, proposals for actions have a stronger technocratic and positivist perspective detached from a value-based discussion. Other guideline documents based on sustainability principles have been shown to fail to provide an explicit recommendation to apply such principles [27]. Even for sustainability science, a focus on environmental aspects of sustainability hinders interdisciplinarity [45]. Moving from discourse to holistic sustainability practices is a challenge faced by practitioners worldwide [44], one that the PNA has a minimal contribution to overcome.

The prevalence of explicit mentions of the Ecological category reflects the focus on ecological sustainability. The maintenance and restoration of ecosystems and their services 
are central to the adaptation approach based on ecosystems [38] and a priority target for the ecosystem approach $[41,46]$. EBM ecological principles are commonly explicit in environmental management policies, even if only as a foundational theoretical concept $[23,27]$. However, for existing Brazilian coastal management policies, their presence is not sufficient to promote EBM [47].

Indeed, EBM Ecological and Management categories are shared by many management frameworks and appear in many policies, regardless of their direct relation to the EBM approach. For instance, Brazilian's National Coastal Management Plan (Federal Law 7661/1988) is based on the Integrated Coastal Management Framework that advocates for Integrated and Adaptive Management [48]; other federal legislation dwells on the need for integrated and adaptive management, as the Water and Energy policies or the National Strategic Plan for Protected Areas [47]. The presence of such Management category in the General Guidance and Propositive sections reinforces their commitment and a strong emphasis on "Appropriate Monitoring" to guide actions. Monitoring is crucial to CC adaptation [49], and the Procosta itself embodies this recognition as an instrument to generate data to support action.

The low percentage scores of the Democracy and Knowledge categories in both documents also reflect the underrepresentation of social and economic aspects of sustainability in the instruments. Although both instruments recognised the interconnection of human and ecological dimensions - related to the "Recognise Coupled Social-Ecological Systems" principle-by incorporating the concept of ecosystem services [50,51], the need to actively promote stakeholder involvement as to incorporate societal choices in adaptation policies is undervalued. The broadened definition of the "Stakeholder Involvement" principle applied in this analysis resulted in a high percentage of explicit mentions of this principle that conceals that proposed involvement is limited to information sharing.

Information sharing is a basal technique for democratic practices and is essential to raise social awareness towards CC. However, spinning the wheel of participation towards more active social involvement is necessary when planning for CC in the Global South [3,52]. More inclusive planning processes correspond to higher climate equity and justice outcomes in the short term [5]. Involving stakeholders in the public decision-making process is a challenge that requires managing representativeness, access to resources, transparency and power (im)balance, enforcement and inclusion of usually marginalised populations [53,54]. In Brazil, coastal management processes deal with this challenge $[55,56]$, exacerbated by the high social vulnerabilities and the unbalanced distribution of richness in the coast [33]. Although some advances exist, recent retrocession in environmental practices jeopardizes the rights for social participation [54]. With the implicit mentions on how to actively involve stakeholders in PNA and Procosta actions, these instruments have limited contribution to advancing democratic practices.

Of the many social sectors that must be involved in adaptation policy-making, the academic sector finds more room for participation, if only in paper, given the recognition of the importance of the use of interdisciplinary scientific knowledge on PNA and Procosta. CC impacts natural processes and may intensify natural hazards [2,3]. Management strategies need information on such natural processes to identify and predict the impacts of CC. A more exhaustive comprehension of how ecosystems vary across space and time, through environmental baseline studies, may offer more reliability on if and how CC impacts the ecosystems, their functions, and, consequently, the ecosystem services provided by them. This is one of the purposes of the Procosta; nevertheless, the percentage score for the Knowledge category was relatively low for the documents analysed.

The "Acknowledge Uncertainty" principle was the only principle absent in both instruments. Uncertainty is an intrinsic characteristic of the Anthropocene's complex problems [57,58], especially considering CC [59,60]. Uncertainty manifests itself in various ways, such as the lack of knowledge on aspects of the social-ecological ecosystem, the impacts and consequences of $\mathrm{CC}$ and management actions to adapt to them and their consequences [41,61]. Acknowledging and finding new practices to quantify (when 
possible), communicate and make decisions in the face of uncertainty is a crucial management need $[49,55,61]$. Considering the dynamics and innumerable interactions of social-ecological systems, "planning becomes the management of uncertainty-dealing with non-linear coupled human-nature systems and making preparations for changes and surprises" [62] (p. 101). Dealing with uncertainty is a critical component of EBM and strongly relates to other principles, such as "Adaptive Management" [41,61]. Structuring a national plan for adaptation without acknowledging existing and future uncertainties may interfere with the overall adaptation strategy.

Communicating and dealing with uncertainty is also central for the science-policy interface and the application of scientific knowledge in climate policy [63]. It is interesting to note that implicit mentions of the use of scientific knowledge account for half of the extracts in PNA and more than eighty per cent in Procosta (Figure 2c,d). In practice, however, the instruments rely on the collaboration between research organisations and governmental agencies. The Rede Clima, a national research network to produce and disseminate climatic information that can assist in public policy formulation, has a sub-group that focuses on specific coastal demands and works to support PNA implementation [64]. Since its launch, the small advances registered for Procosta implementation are supported by research projects across the Brazilian coast [65]. These initiatives are affected by historical and ongoing investment cuts $[66,67]$ that menace the instrument's effective implementation.

Procosta explicit references to the Scale category are an advancement in their application of an adaptation strategy. Scale mismatch between social and ecological processes is a recurring challenge in social-ecological systems' study and management $[68,69]$. Boundary setting entails physically defining a system, giving meaning to the situation, and defining what should be considered for management purposes [70]. Many marine resources and ecological processes that support human well-being transcend political boundaries [70,71]. Defining appropriate scales and considering scales and cross-scales, interplay is fundamental to environmental management $[68,69]$. It can be supposed that, by considering the Coastal Zone as a theme subject to specific attention in the PNA, the document acknowledges its boundaries' singularities. Nevertheless, to guide EBM implementation, it would also be necessary to allude to such a category in the Propositive sections explicitly. Procosta addressed this issue with prevailing explicit mentions, but the lack of clarity to guide implementation on the instrument may impair other sectoral programs related to the PNA.

Our analysis shows that, although Brazilian federal instruments to CC adaptation explicitly reference EBM principles, the unbalanced focus in some principles' categories impair such instruments' capacity to foster EBM. The explicit reference to the ecosystem approach to CC adaptation alone demonstrates the national adaptation strategy's innovative potential. Providing the legal provision to include EBM in the adaptation agenda can trigger its application to specific regulations built upon general rules [25]. EBM is an integrated approach that demands the concurrent application of all principles' categories. Unbalanced references to the categories do not invalidate the instruments as EBM promoters; however, overlooked principles represent challenges for implementing other coastal management policies (as Sustainability and Democracy categories) and indicate that the obstacles are more significant than they appear at first glance.

Since academic researchers performed the analysis here, it is relevant to notice that the identification of explicit and implicit mentions is denoted by our understanding and knowledge of EBM practices. Similar studies, in which homogeneous group analyses a process [25,27], share this degree of subjectivity. The effort to collectively discuss the concepts and the successive debates for consensuses over classifications was an attempt to lower the authors' bias. Despite this, it is reasonable to expect that other groups of stakeholders would have a different perception of what is and what is not an explicit mention of an EBM principle. Additionally, we discuss the potential for operationalisation, focusing on Propositive sections, in these two federal instruments. Lower-level instruments and application of the principles in situ should follow federal directives, but this is not 
a rule given the discrepancies among administrative levels [23]. An analysis of similar instruments at lower levels (state and municipal adaptation plans) can clarify how EBM principles run downstream from the federal guideline. Few states or municipalities have already implemented their adaptation plan, but some efforts are in place that will soon enable such further analysis [60]. A preliminary analysis of the adaptation plan for Santos municipality (São Paulo/Brazil) shows a similar trend in unbalanced reference to different principles' categories (unpublished data by the authors).

\section{Conclusions}

In Brazil, two principal adaptation instruments, the PNA and Procosta, incorporate an ecosystem-based adaptation approach that could be a strategy to translating EBM principles into actions. However, unbalanced attention to some principles (Democracy, Knowledge and Scale categories) and the fact that others are absent or only implicitly recognisable in Propositive sections of the instruments (as "Sustainability" and "Acknowledge Uncertainty" principles) show that the instruments have limited potential to promote EBM. To change this tide, attention must be given to define EBM principles and explicitly include them on policy goals, directives and objective proposals for action.

Moving from paper to practice still faces historical obstacles related to a single set of principles (as democratic ones). In Brazil, the federative pact establishes the national set of public policies' primacy to determine general rules and guidelines, while states and municipalities are responsible for implementing them [72]. Implementing EBM in this context entails confronting historical political restraints related to resource distribution, power imbalance and process continuity. The current government presents a significant challenge to implement and move EBM-based CC adaptation from paper to practice. The consecutive cuts of investments in science and technology $[66,67]$, and the negationist reaction of the central government concerning scientific recommendation to $\mathrm{CC}$ [73] and COVID-19 [74], are actions that jeopardise pre-established science-policy interactions [64]. In addition, recent actions have dismantled participative management bodies and the country's environmental policies [73,75], built progressively over the last four decades [76]

Besides the recommendations for considering the perception of a broad range of stakeholders on the analysis and expanding it to instruments from different administrative levels, EBM implementation will benefit from studies that focus on the challenges to address distinct principles' categories and how to move on with sustainability democratisation agendas. Linking the EBM-adaptation agenda to other relevant scientific debates is also a field to be explored. In Brazil, EBM emerges as a great option to link adaptation with actions that address vulnerability's underlying causes. However, the discussion of addressing inequalities and promoting just sustainability [44] is incipient in scientific literature and policy arenas [77]. Discussions on how to apply EBM to shift ongoing and emergent practices towards transformative adaptation are equally desirable. For the Global South and the least developed countries, transformational adaptation is increasingly recognised as a necessary response to $\mathrm{CC}$ as incremental adaptation is insufficient for alleviating the global poor's vulnerability [78]. Transformational adaptation should be considered early to adapt to CC and become a goal in plans and programs. For this, academics, policy makers and managers must work in close cooperation.

Indeed, advancing science-policy integration is a way forward in enhancing and implementing EBM. Collaborative work of policy and decision-makers, academics and non-academic society is crucial for EBM implementation in Brazil and elsewhere. Policy and decision-makers should be aware of EBM's logic and the elements recognised as compatible with the approach. As an example of science-policy interaction, capacitybuilding programs can improve the technical capacity of policy and decision makers to evaluate needs and incorporate EBM into their practices, creating the conditions to facilitate its operationalisation [27].

Science-policy collaboration in translating and defining EBM and its concept as legal provisions is also required. Besides the little attention given to some principles, unclear 
and vague mentions of the approach and its principles allow ineffective implementation. Future documents should avoid the use of broad and general directions such as "to value EBA actions" [38] (p. 359). The quotation calls attention to the importance of ecosystembased adaptations (EBA) but does not specify (a) which actions or (b) how to operate as to value them. Policy makers can address the principles' definition with aid from academia. Legal definitions of core EBM principles might differ from the scientific literature [25], and clarifying and aligning them to specific contexts can guarantee a cohesive discourse that propels developments in both fields.

While academic research has increasingly supported EBM as essential to integrate and promote solutions to human-social complex systems as coastal zones, in practice, it is still far from engaging decision makers in its application. To push a wave of change, EBM requires a government that, instead of dismantling environmental policies, supports and implements a robust framework aiming to foster just sustainability. This research is one of the few studies that empirically assesses how legal provisions take EBM principles into account, inspiring future research on the subject. If EBM becomes a baseline for CC adaptation, it will undoubtedly contribute, to say the least, to a more holistic and transformative approach rather than sectorial and traditional management.

Supplementary Materials: The following are available online at https:/ / www.mdpi.com/article/10.3 390/su14031317/s1, Table S1: Ecosystem-based management principles, categories and definitions considered for the analysis of Climate Change Policy instruments in Brazil, Table S2: EBM principles considered for the analysis of Climate Change Policy instruments in Brazil (based on the review of Long et al., 2015) and examples of the extracts from the documents according to the classification applied in this study: 1-implicitly mentioned or 2-explicitly mentioned.

Author Contributions: Conceptualization, L.Y.X., M.G., L.R.G., M.R.C. and A.T.; methodology M.G. and A.T.; validation, L.Y.X., M.G., L.R.G. and M.R.C.; formal analysis, L.Y.X., M.G., L.R.G. and M.R.C.; investigation, L.Y.X., M.G., L.R.G. and M.R.C.; writing—original draft preparation, L.Y.X., M.G., L.R.G. and M.R.C.; writing-review and editing, L.Y.X., M.G., L.R.G., M.R.C. and A.T.; visualization, L.Y.X., M.G., L.R.G. and M.R.C. All authors have read and agreed to the published version of the manuscript.

Funding: This research was funded by Fundação de Amparo à Pesquisa do Estado de São PauloFAPESP, grants number LYX: 2017/21797-5 and 2019/13851-5; MG: 2016/24677-8 and 2019/14537-2; LRG: 2018/00462-8 and 2019/04481-0; MRC: 2018/13238-9; and the National Council for Scientific and Technological Development-CNPq, grant numbers AT: 309697/2015-8 and 310553/2019-9.

Data Availability Statement: Not applicable.

Acknowledgments: This research is part of the activities of the Thematic Project "Environmental Governance of the Paulista Macrometropolis in face of climate variability" (FAPESP 2015/03804-9), the regular project "Fostering the ecosystem-based approach in beach spatial planning and conservation" (FAPESP 2018/19776-2) and of the project "Será que vai dar praia? Inovações para a sustentabilidade dos oceanos" (Fundação Grupo Boticário 1133_20182).

Conflicts of Interest: The authors declare no conflict of interest.

\section{References}

1. Halpern, B.S.; Frazier, M.; Afflerbach, J.; Lowndes, J.S.; Micheli, F.; O’Hara, C.; Scarborough, C.; Selkoe, K.A. Recent pace of change in human impact on the world's ocean. Sci. Rep. 2019, 9, 1-8. [CrossRef]

2. Doney, S.C.; Ruckelshaus, M.; Emmett Duffy, J.; Barry, J.P.; Chan, F.; English, C.A.; Galindo, H.M.; Grebmeier, J.M.; Hollowed, A.B.; Knowlton, N.; et al. Climate change impacts on marine ecosystems. Ann. Rev. Mar. Sci. 2012, 4, 11-37. [CrossRef] [PubMed]

3. Torres, P.H.C.; Jacobi, P.R.; Barbi, F.; Gonçalves, L.R. Adaptation and Public Policies in the São Paulo Macrometropolis: A Science-Policy Approach, 1st ed.; IEE-USP: São Paulo, Brazil, 2020; ISBN 978-86923-59-3. Available online: https:// repositorio.ul.pt/bitstream/10 451/45573/1/ICS_LSchmidt_CGomes_.pdf (accessed on 10 January 2022).

4. Fernandino, G.; Elliff, C.I.; Silva, I.R. Ecosystem-based management of coastal zones in face of climate change impacts: Challenges and inequalities. J. Environ. Manag. 2018, 215, 32-39. [CrossRef]

5. Chu, E.; Anguelovski, I.; Camin, J. Inclusive approaches to urban climate adaptation planning and implementation in the Global South. Clim. Policy 2016, 16, 372-392. [CrossRef] 
6. IPCC (Intergovernmental Panel on Climate Change). Climate Change 2014: Impacts, Adaptation, and Vulnerability. Part B: Regional Aspects. Contribution of Working Group II to the Fifth Assessment Report of the Intergovernmental Panel on Climate Change; Barros, V.R., Field, C.B., Dokken, D.J., Mastrandrea, M.D., Mach, K.J., Bilir, T.E., Chatterjee, M., Ebi, K.L., Estrada, Y.O., Genova, R.C., et al., Eds.; Cambridge University Press: Cambridge, UK, 2014; ISBN 9781107683860.

7. Nelson, D.R.; Adger, W.N.; Brown, K. Adaptation to Environmental Change: Contributions of a Resilience Framework. Annu. Rev. Environ. Resour. 2007, 32, 395-419. [CrossRef]

8. Pittman, J.; Armitage, D.; Alexander, S.; Campbell, D.; Alleyne, M. Governance fit for climate change in a Caribbean coastal-marine context. Mar. Policy 2015, 51, 486-498. [CrossRef]

9. Ruckelshaus, M.; Doney, S.C.; Galindo, H.M.; Barry, J.P.; Chan, F.; Duffy, J.E.; English, C.A.; Gaines, S.D.; Grebmeier, J.M.; Hollowed, A.B.; et al. Securing ocean benefits for society in the face of climate change. Mar. Policy 2013, 40, 154-159. [CrossRef]

10. Vignola, R.; Locatelli, B.; Martinez, C.; Imbach, P. Ecosystem-based adaptation to climate change: What role for policy-makers, society and scientists? Mitig. Adapt. Strateg. Glob. Chang. 2009, 14, 691-696. [CrossRef]

11. Munang, R.; Thiaw, I.; Alverson, K.; Mumba, M.; Liu, J.; Rivington, M. Climate change and Ecosystem-based Adaptation: A new pragmatic approach to buffering climate change impacts. Curr. Opin. Environ. Sustain. 2013, 5, 67-71. [CrossRef]

12. Therville, C.; Brady, U.; Barreteau, O.; Bousquet, F.; Mathevet, R.; Dhenain, S.; Grelot, F.; Brémond, P. Challenges for local adaptation when governance scales overlap. Evidence from Languedoc, France. Reg. Environ. Chang. 2019, 19, $1865-1877$. [CrossRef]

13. Biesbroek, G.R.; Klostermann, J.E.M.; Termeer, C.J.A.M.; Kabat, P. On the nature of barriers to climate change adaptation. Reg. Environ. Chang. 2013, 13, 1119-1129. [CrossRef]

14. Lukasiewicz, A.; Pittock, J.; Finlayson, M. Institutional challenges of adopting ecosystem-based adaptation to climate change. Reg. Environ. Chang. 2016, 16, 487-499. [CrossRef]

15. Long, R.D.; Charles, A.; Stephenson, R.L. Key principles of marine ecosystem-based management. Mar. Policy 2015, 57, 53-60. [CrossRef]

16. Arkema, K.K.; Abramson, S.C.; Dewsbury, B.M. Marine ecosystem-based management: From characterization to implementation. Front. Ecol. Environ. 2006, 4, 525-532. [CrossRef]

17. Lester, S.E.; McLeod, K.L.; Tallis, H.; Ruckelshaus, M.; Halpern, B.S.; Levin, P.S.; Chavez, F.P.; Pomeroy, C.; McCay, B.J.; Costello, C.; et al. Science in support of ecosystem-based management for the US West Coast and beyond. Biol. Conserv. 2010, 143, 576-587. [CrossRef]

18. Rudd, M.A.; Dickey-Collas, M.; Ferretti, J.; Johannesen, E.; Macdonald, N.M.; McLaughlin, R.; Rae, M.; Thiele, T.; Link, J.S. Ocean ecosystem-based management mandates and implementation in the North Atlantic. Front. Mar. Sci. 2018, 5. [CrossRef]

19. Sardá, R.; Valls, J.F.; Pintó, J.; Ariza, E.; Lozoya, J.P.; Fraguell, R.M.; Martí, C.; Rucabado, J.; Ramis, J.; Jimenez, J.A. Towards a new Integrated Beach Management System: The Ecosystem-Based Management System for Beaches. Ocean Coast. Manag. 2015, 118, 167-177. [CrossRef]

20. Curtin, R.; Prellezo, R. Understanding marine ecosystem based management: A literature review. Mar. Policy 2010, 34, 821-830. [CrossRef]

21. O'Higgins, T.G.; Lago, M.; Dewitt, T.H. Ecosystem-Based Management, Ecosystem Services and Aquatic Biodiversity: Theory, Tools and Applications; Springer Nature Switzerland AG: Cham, Switzerland, 2020; ISBN 9783030458423.

22. Langlet, D.; Rayfuse, R. The Ecosystem Approach in Ocean Planning and Governance: Perspectives from Europe and Beyond; Langlet, D., Rayfuse, R., Eds.; Koninklijke Brill NV: Leiden, The Netherlands, 2018; ISBN 9789004389984.

23. Scarano, F.R. Ecosystem-based adaptation to climate change: Concept, scalability and a role for conservation science. Perspect. Ecol. Conserv. 2017, 15, 65-73. [CrossRef]

24. Cormier, R.; Kelble, C.R.; Anderson, M.R.; Allen, J.I.; Grehan, A.; Gregersen, Ó. Moving from ecosystem-based policy objectives to operational implementation of ecosystem-based management measures. ICES J. Mar. Sci. 2017, 74, 406-413. [CrossRef]

25. Gelcich, S.; Reyes-Mendy, F.; Arriagada, R.; Castillo, B. Assessing the implementation of marine ecosystem based management into national policies: Insights from agenda setting and policy responses. Mar. Policy 2018, 92, 40-47. [CrossRef]

26. Enright, S.R.; Boteler, B. The Ecosystem Approach in international environmental law and governance. In Ecosystem-Based Management, Ecosystem Services and Aquatic Biodiversity: Theory, Tools and Applications; O'Higgins, T.G., Lago, M., DeWitt, T.H., Eds.; Springer Nature Switzerland AG: Cham, Switzerland, 2020; pp. 333-352, ISBN 9783030458430.

27. Guilhon, M.; Montserrat, F.; Turra, A. Recognition of ecosystem-based management principles in key documents of the seabed mining regime: Implications and further recommendations. ICES J. Mar. Sci. 2020. [CrossRef]

28. PBMC. Impacto, Vulnerabilidade e Adaptação das Cidades Costeiras Brasileiras às Mudanças Climáticas; Marengo, J.A., Scarano, F.R., Eds.; PBMC, COPPE-UFRJ: Rio de Janeiro, Brazil, 2016; ISBN 9781479917853.

29. Nicolodi, J.L.; Petermann, R.M. Mudanças Climáticas e a Vulnerabilidade da Zona Costeira do Brasil: Aspectos ambientais, sociais e tecnológicos. Rev. Gestão Costeira Integr. 2010, 10, 151-177. [CrossRef]

30. Barbi, F.; Ferreira, d.C.L. Risks and political responses to climate change in Brazilian coastal cities. J. Risk Res. 2014, 17, 485-503. [CrossRef]

31. Prates, A.P.L.; Gonçalves, M.A.; Rosa, M.R. Panorama da Conservação dos Ecossistemas Costeiros e Marinhos no Brasil, 2nd ed.; Ministério do Meio Ambiente (MMA): Brasília, Brazil, 2012; ISBN 9788577381425. 
32. Marengo, J.A. Mudanças Climáticas Globais e seus Efeitos sobre a Biodiversidade: Caracterização do Clima Atual e Definição das Alterações Climáticas para o Território Brasileiro ao Longo do Séculp XXI, 2nd ed.; Ministério do Meio Ambiente (MMA): Brasílila, Brazil, 2007; ISBN 8577380386.

33. do Carmo, R.L.; da Silva, C.A.M.; de Miranda, Z.A.I. Dinâmica demográfica, economia e ambiente na zona costeira de São Paulo. Textos NEPO 2012, 63, 18-24. Available online: http://www.nepo.unicamp.br/publicacoes/textos_nepo/textos_nepo_63.pdf (accessed on 10 January 2022).

34. Iwama, A.Y.; Batistella, M.; Ferreira, L.d.C. Riscos geotécnicos e vulnerabilidade social em zonas costeiras: Desigualdades e mudanças climáticas. Ambient. Soc. 2014, 17, 251-274. [CrossRef]

35. Leal Filho, W.; Freitas, L.E. Climate Change Adaptation in Latin America: Managing Vulnerability, Fostering Resilience, 1st ed.; Leal, F.W., Freitas, L.E., Eds.; Springer Nature Switzerland AG: Cham, Switzerland, 2018; ISBN 9783319569468.

36. Ministério do Meio Ambiente. Plano Nacional de Adaptação à Mudança do Clima-Volume I: Estratégia Geral; Ministério do Meio Ambiente (MMA): Brasília, Brazil, 2016; Volume 1.

37. Ministério do Meio Ambiente. Plano Nacional de Adaptação à Mudança do Clima-Volume II: Estratégias Setoriais e Temáticas; Ministério do Meio Ambiente (MMA): Brasília, Brazil, 2016; Volume 2.

38. Travers, A.; Elrick, C.; Robert, K.; Vestergaard, O. Ecosystem-Based Adaptation Guidance: Moving from Policy to Practice; United Nations Environment Programme: Nairobi, Kenya, 2012.

39. Ministério do Meio Ambiente. Programa Nacional para a Conservação da Linha de Costa; Ministério do Meio Ambiente (MMA): Brasília, Brazil, 2018; ISBN 9788577381012.

40. United Nations Transforming our World: The 2030 Agenda for Sustainable Development 2015, A/RES/70/1, 41. Available online: https://sdgs.un.org/sites/default/files/publications/21252030\%20Agenda\%20for\%20Sustainable\%20Development $\%$ 20web.pdf (accessed on 10 January 2022).

41. CBD Secretariat (Secretariat of the Convention of Biological Diversity). The Ecosystem Approach (CBD Guidelines); Secretariat of the Convention on Biological Diversity: Montreal, QC, Canada, 2004; ISBN 9292250248.

42. ICLEI. Fundação Grupo Boticário. Adaptação Baseada em Ecossistemas: Oportunidades para Políticas Públicas em Mudanças Climáticas; ICLEI: Curitiba, Brazil, 2014. Available online: https://e-lib.iclei.org/wp-content/uploads/2018/10/Adapata\%C3\%A7\%C3\%A3 O_baseada_em_ecossistemas.pdf (accessed on 10 January 2022).

43. Borgström, S.; Bodin, Ö.; Sandström, A.; Crona, B. Developing an analytical framework for assessing progress toward ecosystembased management. Ambio 2015, 44, 357-369. [CrossRef] [PubMed]

44. Agyeman, J. Toward a "just" sustainability? Continuum 2008, 22, 751-756. [CrossRef]

45. Schoolman, E.D.; Guest, J.S.; Bush, K.F.; Bell, A.R. How interdisciplinary is sustainability research? Analyzing the structure of an emerging scientific field. Sustain. Sci. 2012, 7, 67-80. [CrossRef]

46. Granek, E.F.; Polasky, S.; Kappel, C.V.; Reed, D.J.; Stoms, D.M.; Koch, E.W.; Kennedy, C.J.; Cramer, L.A.; Hacker, S.D.; Barbier, E.B.; et al. Ecosystem services as a common language for coastal ecosystem-based management. Conserv. Biol. 2010, 24, 207-216. [CrossRef] [PubMed]

47. Araujo, F.C.B. Desafios à adoção da abordagem ecossistêmica como instrumento jurídico para a gestão de recursos marinhos na zona costeira brasileira. In Meio ambiente marinho e Direito-Volume II: A gestão sustentável dos recursos marinhos na zona costeira e no espaço marinho; de Oliveira, C.C., Galindo, G.R.B., Silva, S.T., Montalverne, T., Eds.; Juruá Editora: Curitiba, Brazil, 2018; Volume 2, pp. 61-84, ISBN 9788536275802. Available online: https://www.jurua.com.br/shop_item.asp?id=26492 (accessed on 10 January 2022).

48. Cicin-Sain, B.; Knecht, R.W.W. Integrated Coastal Management: Concepts and Practices; Island Press: Washington, DC, USA/Covelo, CA, USA, 1998.

49. Carpenter, S.R.; Gunderson, L.H. Coping with Collapse: Ecological and Social Dynamics in Ecosystem Management. Bioscience 2001, 51, 451-457. [CrossRef]

50. Schröter, M.; van der Zanden, E.H.; van Oudenhoven, A.P.E.; Remme, R.P.; Serna-Chavez, H.M.; de Groot, R.S.; Opdam, P. Ecosystem Services as a Contested Concept: A Synthesis of Critique and Counter-Arguments. Conserv. Lett. 2014, 7, 514-523. [CrossRef]

51. Markus, T.; Hillebrand, H.; Hornidge, A.K.; Krause, G.; Schlüter, A. Disciplinary diversity in marine sciences: The urgent case for an integration of research. ICES J. Mar. Sci. 2018, 75, 502-509. [CrossRef]

52. Braun, R. Social participation and climate change. Environ. Dev. Sustain. 2010, 12, 777-806. [CrossRef]

53. Trimble, M.; de Araujo, L.G.; Seixas, C.S. One party does not tango! Fishers' non-participation as a barrier to co-management in Paraty, Brazil. Ocean Coast. Manag. 2014, 92, 9-18. [CrossRef]

54. Glaser, M.; Xavier, L.Y.; Barboza, R.S.L.; Borges, R.; Blandtt, L.; Gerhardinger, L.C.; Ferreira, B.P.; Marques, S.; Gonçalves, L.R.; Turra, A. Social participation in coastal and ocean management in Brazil: Lessons learnt and ways ahead. ZMT Policy Brief 7. 2020. Available online: https://www.leibniz-zmt.de/images/content/pdf/Policy_Briefs/Policy_Brief_Participation_Brazil_ ENG_20200514.pdf (accessed on 10 January 2022).

55. Polette, M.; Muehe, D.; Soares, M.L.G.; Glavovic, B.C. The promise of coastal management in Brazil in times of global climate change. In Climate Change and the Coast: Building Resilient Communities; Glavovic, B.C., Kelly, M., Kay, R., Travers, A., Eds.; CRC Press: London, UK, 2015; pp. 379-413, ISBN 9781482288582. 
56. Wever, L.; Glaser, M.; Gorris, P.; Ferrol-Schulte, D. Decentralization and participation in integrated coastal management: Policy lessons from Brazil and Indonesia. Ocean Coast. Manag. 2012, 66, 63-72. [CrossRef]

57. Chapin III, F.S.; Carpenter, S.R.; Kofinas, G.P.; Folke, C.; Abel, N.; Clark, W.C.; Olsson, P.; Smith, D.M.S.; Walker, B.; Young, O.R.; et al. Ecosystem stewardship: Sustainability strategies for a rapidly changing planet. Trends Ecol. Evol. 2010, 25, 241-249. [CrossRef]

58. Glaser, M.; Krause, G.; Ratter, B.M.W.; Welp, M. (Eds.) Human-Nature Interactions in the Anthropocene: Potentials of Social-Ecological Systems Analysis; Routledge: New York, NY, USA, 2012; ISBN 9780415510004.

59. Eisenack, K.; Moser, S.C.; Hoffmann, E.; Klein, R.J.T.; Oberlack, C.; Pechan, A.; Rotter, M.; Termeer, C.J.A.M. Explaining and overcoming barriers to climate change adaptation. Nat. Clim. Chang. 2014, 4, 867-872. [CrossRef]

60. Barbi, F.; Ferreira, L.d.C. Governing Climate Change Risks: Subnational Climate Policies in Brazil. Chin. Polit. Sci. Rev. 2017, 2, 237-252. [CrossRef]

61. Boesch, D.F. Scientific requirements for ecosystem-based management in the restoration of Chesapeake Bay and Coastal Louisiana. Ecol. Eng. 2006, 26, 6-26. [CrossRef]

62. Ratter, B.M.W. Complexity and emergence: Key concepts in non-linear dynamic systems. In Human-Nature Interactions in the Anthropocene; Glaser, M., Krause, G., Ratter, B.M.W., Welp, M., Eds.; Routledge: New York, NY, USA, 2012; pp. 108-122, ISBN 9780415510004.

63. Meah, N. Climate uncertainty and policy making-What do policy makers want to know? Reg. Environ. Chang. 2019, 19, 1611-1621. [CrossRef]

64. Copertino, M.S.; Garcia, C.A.; Turra, A.; Ciotti, Á.M.; Gherardi, D.; Denadai, M.R.; Möller, O.; Raggi, P.; Horta, P.A.; Kikuchi, R.P.K.; et al. Zonas Costeiras. In Mudanças Climáticas em Rede Um olhar Interdisciplinar: Contribuições do Instituto Nacional de Ciência e Tecnologia para Mudanças Climáticas; Nobre, C.A., Marengo, J.A., Eds.; INCT: São José dos Campos, Brazil, 2017; p. 608, ISBN 9788579174636.

65. Xavier, L.Y.; Gonçalves, L.R.; De Oliveira, M.; Corrêa, M.R.; Malinconico, N.; Polette, M.; Turra, A. Beach Management and Conservation in Brazil: Challenges and opportunities. In Brazilian Sandy Beaches; Amaral, A.C.Z., Checon, H.H., Corte, G.N., Eds.; Springer: Berlin/Heidelberg, Germany, 2021; in press.

66. Fernandes, G.W.; Vale, M.M.; Overbeck, G.E.; Bustamante, M.M.C.; Grelle, C.E.V.; Bergallo, H.G.; Magnusson, W.E.; Akama, A.; Alves, S.S.; Amorim, A.; et al. Dismantling Brazil's science threatens global biodiversity heritage. Perspect. Ecol. Conserv. 2017, 15, 239-243. [CrossRef]

67. Angelo, C. Brazil's scientists battle to escape 20-year funding freeze. Nature 2016, 539, 480. [CrossRef] [PubMed]

68. Glaser, M.; Glaeser, B. Towards a framework for cross-scale and multi-level analysis of coastal and marine social-ecological systems dynamics. Reg. Environ. Chang. 2014, 14, 2039-2052. [CrossRef]

69. Gonçalves, L.R.; Oliveira, M.; Turra, A. Assessing the Complexity of Social-Ecological Systems: Taking Stock of the Cross-Scale Dependence. Sustainability 2020, 12, 6236. [CrossRef]

70. Halliday, A.; Glaser, M. Management Perspective on Social Ecological Systems: A generic system model and its application to a case study from Peru. Res. Hum. Ecol. 2011, 18, 1-18.

71. Rosen, F.; Olsson, P. Institutional entrepreneurs, global networks, and the emergence of international institutions for ecosystembased management: The Coral Triangle Initiative. Mar. Policy 2013, 38, 195-204. [CrossRef]

72. Carneiro, J.M.B.; Frey, K. Goverança Multinível e Desenvolvimento Regional Sustentável: Experiências do Brasil e da Alemanha, 1st ed.; Oficina Municipal: São Paulo, Brazil, 2018; ISBN 9788589739085.

73. Ferrante, L.; Fearnside, P.M. Brazil's new president and "ruralists" threaten Amazonia's environment, traditional peoples and the global climate. Environ. Conserv. 2019, 46, 261-263. [CrossRef]

74. Caponi, S. COVID-19 no Brasil: Entre o negacionismo e a razao neoliberal. Estud. Avancados 2020, 34, 209-224. [CrossRef]

75. Seixas, C.S.; Pado, D.S.; Joly, C.A.; May, P.H.; Neves, E.M.S.C.; Teixeira, L.R. Governança ambiental no Brasil: Rumo aos objetivos do desenvolvimento sustentável (ODS)? Cad. Gestão Pública Cid. 2020, 25, 1-21. [CrossRef]

76. Araújo, S.M.V.G. de Environmental Policy in the Bolsonaro Government: The Response of Environmentalists in the Legislative Arena. Brazilian Polit. Sci. Rev. 2020, 14, 1-20. [CrossRef]

77. Torres, P.H.C.; Leonel, A.L.; de Araújo, G.P.; Jacobi, P.R. Is the Brazilian National Climate Change Adaptation Plan Addressing Inequality? Climate and Environmental Justice in a Global South Perspective. Environ. Justice 2020, 13, 42-46. [CrossRef]

78. Kates, R.W.; Travis, W.R.; Wilbanks, T.J. Transformational adaptation when incremental adaptations to climate change are insufficient. Proc. Natl. Acad. Sci. USA 2012, 109, 7156-7161. [CrossRef] [PubMed] 